\title{
Correction to: The Anomalous Nucleation in Al-Tb Metallic Glasses
}

\author{
T.H. ULUCAN, I. KALAY, and Y.E. KALAY \\ https://doi.org/10.1007/s11661-021-06487-z \\ (c) The Minerals, Metals \& Materials Society and ASM International 2021
}

\section{Correction to:}

Metallurgical and Materials Transactions A, Volume 52A, February 2021 https://doi.org/10.1007/s11661-020-06111-6

THE following was inadvertently omitted from the Acknowledgments in the original article:

The authors would like to thank Dr. Can Yildirım for collecting and sharing the DSC data used in Figure 12 and Dr. Mustafacan Kutsal for his contribution in collecting synchrotron XRD data used in Figure 1.

Publisher's Note Springer Nature remains neutral with regard to jurisdictional claims in published maps and institutional affiliations.

T.H. ULUCAN and Y.E. KALAY are with the Department of Metallurgical and Materials Engineering, METU, 06800, Ankara, Turkey. Contact e-mail: ekalay@metu.edu.tr I. KALAY is with the Department of Materials Science and Engineering, Cankaya University, 06790, Ankara, Turkey.

The original article can be found online at https://doi.org/10.1007/ s11661-020-06111-6.

Article published online October 12, 2021 